\title{
Elevation of anti-oxidative activity and inhibitory activities against tyrosinase, elastase, collagenase and hyaluronidase of Oplismenus undulatifolius by elicitor treatment
}

\author{
Eun-Ho Lee ${ }^{1}$ (D) $\cdot$ Young-Je Cho ${ }^{1}$ (D) \\ Elicitor 처리한 주름조개풀(Oplismenus undulatifolius)의 항산화,
tyrosinase, elastase, collagenase 및 hyaluronidase 억제 활성 증대
}

이은호 ${ }^{1} \cdot$ 조영제 ${ }^{1}$

Received: 22 July 2020 / Accepted: 20 August 2020 / Published Online: 30 September 2020

(C) The Korean Society for Applied Biological Chemistry 2020

\begin{abstract}
This study was designed to assess the change of the antioxidative and biological enzyme activities [tyrosinase, elastase, collagenase, and hyaluronidase (HAase)] of extracts from elicitortreated Oplismenus undulatifolius. Elicitor-treated O. undulatifolius showed higher total phenolic content than the non-treated extract. As a result of comparing the anti-oxidant activity of elicitortreated $O$. undulatifolius extract and non-treated extract, the elicitor-treated group showed high activity. Elicitor-treated $O$. undulatifolius showed higher elastase and collagenase inhibitory activities as anti-wrinkle effect, tyrosinase inhibitory activity as whitening effect, and anti-inflammation effect to induced as HAase inhibition than the non-treated extract. Therefore, elicitortreatment during $O$. undulatifolius cultivation in outdoors will elevate total phenolics content in the plant and elevate of various bioactivities, which will yield high quality for industrialization.
\end{abstract}

Keywords Anti-oxidant · Biological enzymes · Effective elevation · Elicitor · Oplismenus undulatifolius

Young-Je Cho $(\bowtie)$

E-mail: yjcho@knu.ac.kr

${ }^{1}$ School of Food science \& Biotechnology, Kyungpook National University, 80 University Street, Bukgu, Daegu 41566, Republic of Korea

This is an Open Access article distributed under the terms of the Creative Commons Attribution Non-Commercial License (http://creativecommons. org/licenses/by-nc/3.0/) which permits unrestricted non-commercial use, distribution, and reproduction in any medium, provided the original work is properly cited.

\section{서 론}

현재 인류의 삶의 질을 높이기 위한 당면과제로 노화 억제가 많은 관심을 받고 있다. 노화억제 내지는 노화 지연에 관한 연 구는 성인병 억제 기술개발과 더불어 피부노화의 억제 및 개선 을 위한 분야에서 많은 연구가 진행되고 있으며, 주된 연구 경 향으로 노화억제를 위한 기능성 물질들의 개발이 진행되고 있 다[1,2]. 많은 연구자들에 의한 기능성 물질의 연구는 인체에 적 용되었을 때 부작용이 거의 없는 천연물이 높은 관심을 받고 있으며, 동양문화권에서 예로부터 치료와 예방의 목적으로 사용 되어온 한약재와 약용식물들에 의해 방어기작으로 생산되는 2 차 대사산물이 가지는 생리활성에 대한 다양한 연구가 진행되 었다[3-5]. 인간의 피부는 노화되어감에 따라 기능저하가 일어 나고, 구조적으로 변화되어 외관상 확연한 시각적 차이를 나타 내게 되는데, 이는 호르몬의 분비 감소, 면역 세포의 기능 저하 로 인해 피부가 얇아져 탄력 감소로 인해 주름이 생성되고, 피 지생성 감소로 인한 피부건조 및 기미와 검버섯 등이 멜라닌 생성으로 인해 발생하며, 얼굴의 명도가 낮아지는 현상이 나타 나게 된다[6,7]. 이러한 피부 노화에 대해서 주름개선, 탄력복원 등의 개선효과를 위해 피부 진피층의 구성물질을 증가시키는 연 구, 노화로 인해 발생하는 피부 흑화 등을 개선하기 위해 멜라 닌 생합성을 억제하는 물질을 개발하여 미용식품에 적용시키는 연구 등이 수행되고 있는 것으로 알려져 있다[8-10]. 이러한 제 품이나 연구에 적용되어 지는 생리활성물질은 합성화합물로 개 발되어 만들어 지는 경우도 있지만, 자연계에서도 동식물 등에 서 흔히 발견되어지고 있다. 자연에 존재하는 생리활성물질 중 에는 식물체가 함유하고 있는 활성물질이 주를 이루는데, 이러 한 활성물질은 자외선에 의한 산화반응이나 곤충들의 공격과 같 
은 외부자극으로부터 자신을 보호하기 위한 방어기작으로 2차 대사산물인 phytochemical 들을 생산하여 세포 내에 함유하며, phytochemical들 중에서 페놀성 화합물은 항산화, 항비만, 항당 뇨, 알레르기 개선, 피부 화이트닝 효과, 주름개선 등 여러 부 분에서 효과를 나타낸다고 보고되고 있다[11,12]. 따라서 약용 식물이나 산채류, 한약재 등에 존재하는 물질의 효능을 탐색하 여 건강기능성 식품이나 항노화를 위한 기능성 소재로 개발하 는 것은 천연자원의 이용과 새로운 식품자원 개발, 신소재 개 발의 측면에서 매우 중요한 의미를 가진다[13]. 국제적으로도 1992년 UN에서 '생물다양성협약 선언문'에 의해 식물자원을 탐 색하여 확보하는 생물산업화 경쟁이 심화되고 있으며, 우리나라 에서도 산림식물 자원에 대한 개발 및 이용이 강조되어지고 있 다[14,15].

주름조개풀(Oplismenus undulatifolius)은 여러해살이로 지표면 에 길게 뻗어 마디에서 뿌리를 내리고 무리지어 살며, 잎이 주 름져 있기 때문에 붙여진 이름이다. 명들내 또는 털주름풀이라 불리며 속씨식물 벼과(Gramineae)의 다년생 초본으로 숲 가장 자리, 밝은 숲 속 등 반음지나 적습한 곳에 주로 서식한다. 우 리나라에서는 중부 이남에 자생하며 세계적으로 난온대-아열대 지리를 중심으로 일본, 대만, 중국, 유럽 등 널리 분포한다[16]. 주름조개풀은 현재까지 약용으로 효능이 크게 밝혀진 바가 없 어 주로 소와 양의 먹이로 이용되었다. 현재 밝혀진 주름조개 풀의 성분으로는 $p$-coumaric acid, luteolin-7-O-glucoside, isoorientin, nigaichigoside $\mathrm{F} 1$, isoscoparin, neoschaftoside, tricin 5-O-glucoside, vicenin-3, neochlorogenic acid, cryptochlorogenic acid, chlorogenic acid 등이 있다[17].

식물체에 존재하는 생리활성물질을 활용하는 연구로 기능성 물질(functional ingredient)의 효율적인 추출을 위한 가공방법 등 의 기술이 연구되고 있으며[18-20], 약용작물이 부가가치 높은 경쟁력을 가지게 할 방안으로 적용되는 elicitation 기술은 식물 이 외부자극이나 외래 병원균 등의 공격을 받을 때 식물체 내 부에서 phytoalexin이라는 성분을 생산하는데 elicitor 처리를 통 해 이를 인위적으로 유도하는 기술로서, 수확기 직전의 짧은 기 간 동안 생산 유도제를 소량 처리하여 유용성분 또는 생리활성 물질의 생성 함량을 높여 보다 고품질의 한방 재료를 생산해 낼 수 있는 획기적인 방법이라 할 수 있다[21,22]. 현재 elicitation 기술은 식물조직세포(callus)의 기내 배양단계에서 사용되고 있 으나, 노지재배에서는 적용 예가 거의 없는 실정이므로, 농가가 재배하는 작물이 아닌 야생초로서 정확한 재배방법이 모색되어 있지 않은 실정이다. 그러므로 본 연구를 진행하기 위해 경북 봉화군 청량산 일대 야생에 분포하는 주름조개풀을 경북대학교 생물학과에서 품종 확인을 한 후, 현지에서 직접 채집하여 경 북대학교 농업생명과학대학 부속실험실습장 내 비닐하우스 M2 실험장에 이식하여 대량 증식 재배를 하며 노지재배 상태에서 elicitor 처리를 하였다.

본 연구에서는 약리성 화합물의 생산성을 높여주는 elicitation 기술 적용 시스템의 적용하여 이에 대한 기술 확립과 주름조개 풀 생체 내 이차대사산물의 생산성과 생리활성 효과를 증가시 키는 것을 목적으로 한다.

\section{재료 및 방법}

\section{생리활성물질유도제(elicitor)의 제조 및 적용}

Elicitor의 제조는 Cho 등의 방법[21]에 의하여 생리활성물질유 도제(elicitor) 분말을 제조하였다. Elicitor의 적용은 노지에서 주 름조개풀의 어린잎이 자라기 시작하는 4 월 하순경부터 잎이 다 자라는 6-7월 하순경까지 1 평 $\left(3.3 \mathrm{~m}^{2}\right)$ 을 기준으로 성장단계 및 평당 주름조개풀의 분포도를 측정하여 1 평당 elicitor 처리 살포 량을 결정하였다. Elicitor 살포량은 처리그룹별 $1 \mathrm{mg} / \mathrm{mL}$ (group $\mathrm{A}$ ), $3 \mathrm{mg} / \mathrm{mL}$ (group B), 및 $5 \mathrm{mg} / \mathrm{mL}$ (group C)의 농도로 설 정하여 1 평당 $1 \mathrm{~L}(1,3,5 \mathrm{~g} / \mathrm{L})$ 를 기준으로 계산하였다. 주름조 개풀의 평당 분포도는 1 차, 2 차, 3 차 처리 시기별로 1 평당 분 포도를 측정하여 $60,80,100 \%$ 로 설정한 후 elicitor를 제조하 였으며, 일정기간에 따라 총 3 회에 걸쳐 elicitor 용액을 제조한 후 분무기를 사용하여 직접 잎에 분무하였다.

\section{추출물의 제조}

Elicitor 처리한 주름조개풀 잎을 수확하여 이물질을 제거한 후, $45^{\circ} \mathrm{C}$ dry oven에서 건조하였다. 건조한 시료는 분쇄기를 이용 하여 $40 \mathrm{mesh}$ 로 분쇄하여 밀봉하여 보관하며 사용하였다. 열수 추출물의 제조는 시료 $1 \mathrm{~g}$ 에 증류수 $200 \mathrm{~mL}$ 를 넣고 가열하여 액이 $100 \mathrm{~mL}$ 이 되었을 때 냉각하였으며, 에탄올 추출물은 $1 \mathrm{~g}$ 의 시료에 $70 \%$ 에탄올 $100 \mathrm{~mL}$ 를 가하여 homogeniger로 $20,000 \mathrm{rpm}$ 에서 1 분간 균질화하였다. 열수, 에탄올 추출물 모두 12 시간 이상 교반 추출하고 추출액은 whatman No. 1 filter paper로 여과하였다.

\section{Total phenolic 정량}

추출물에 함유된 total phenolic compounds의 함량을 측정하기 위해 Folin과 Denis[23]의 방법에 준하여 주름조개풀 추출물 $1 \mathrm{~mL}$, 동량의 $95 \%$ 에탄올 $1 \mathrm{~mL}$ 와 $5 \mathrm{~mL}$ 의 증류수를 첨가한 후 $2 \mathrm{~N}$ 농도의 Folin-ciocalteu reagent를 2 배 희석하여 $0.5 \mathrm{~mL}$ 를 첨가하였다. 이 후 vortex하여 실온에 5 분간 반응시킨 후 발색 시약인 $\mathrm{Na}_{2} \mathrm{CO}_{3} 1 \mathrm{~mL}$ 를 섞어주고 암실에서 1시간 반응시켰다. 측정은 $725 \mathrm{~nm}$ 의 파장에서 흡광도 $(O p t i c a l$ density, $\mathrm{OD})$ 를 측정 하였으며, total phenolic compounds 함량은 gallic acid를 이용 한 표준곡선을 이용하여 정량하였다.

\section{항산화[1,1-diphenyl-2-picrylhydrazyl (DPPH), antioxidant protection factor $(\mathrm{PF})]$ 활성 측정}

라디칼의 생성 여부에 따라 보라색으로 변하는 수용성 항산화 활성 중 DPPH radical 소거능은 Blois의 방법[24]에 준하여 측 정하였다. 주름조개풀 추출물 $1 \mathrm{~mL}$ 에 $60 \mu \mathrm{M} \mathrm{DPPH} 3 \mathrm{~mL}$ 를 첨 가하여 시약이 섞일 수 있게 vortex한 후 15 분 동안 실온에서 시약을 반응시켰다. 측정은 $517 \mathrm{~nm}$ 의 파장에서 흡광도를 측정 하였으며, 추출물의 흡광도와 대조구의 흡광도 차이를 이용하여 계산하였다. $\beta$-Carotene의 산화 정도에 따라 지용성 항산화 활 성을 측정하는 PF는 Andarwulan과 Shetty의 방법[25]에 준하여 측정하였다. Evaporator용 수기에 $\beta$-carotene과 chloroform을 각 
각 $1 \mathrm{mg}$ 당 $5 \mathrm{~mL}$ 비율로 제조하여 $1 \mathrm{~mL}$ 를 넣고 $40-50{ }^{\circ} \mathrm{C}$ water bath에서 용액을 증류시킨 다음, linoleic acid과 tween 40 을 각각 $20,184 \mu \mathrm{L}$ 넣고 $\beta$-carotene을 재용해시킨다. Emulsion 을 제조하기 위해 $50 \mathrm{~mL}$ 의 $\mathrm{H}_{2} \mathrm{O}_{2}$ 를 넣어주고, 주름조개풀 추출 물 $100 \mu \mathrm{L}$ 와 emulsion $5 \mathrm{~mL}$ 을 혼합하여 vortex한 후 $50{ }^{\circ} \mathrm{C}$ 의 water bath에서 30 분간 반응시켜 $470 \mathrm{~nm}$ 의 파장에서 흡광도를 측정하였다.

\section{Tyrosinase 저해 효과 측정}

주름조개풀 추출물의 tyrosinase 저해 효과 측정을 하기 위해 Vincent와 Hearing의 방법[26]에 준하여 실험하였다. 주름조개풀 추출물 $0.2 \mathrm{~mL}$ 와 $0.1 \mathrm{M}$ sodium phosphate buffer $(\mathrm{pH}$ 6.8) 용 액 $2.3 \mathrm{~mL}, 1.5 \mathrm{mM}$ L-tyrosine 농도의 기질 용액 $0.4 \mathrm{~mL}$ 를 혼 합하고, mushroom tyrosinase (Sigma-Aldrich Co, Louis, MO, USA, $250 \mathrm{U} / \mathrm{mL}) 0.1 \mathrm{~mL}$ 를 넣고 $37^{\circ} \mathrm{C}$ 의 water bath에서 20 분 간 시약반응을 시킨 후 $475 \mathrm{~nm}$ 의 파장에서 흡광도를 측정하였다.

\section{Elastase 저해 효과 측정}

피부 탄력을 유지하는 elastin을 분해하여 주름 형성에 영향을 미치는 효소인 elastase 저해 효과를 측정하기 위해 Kraunsoe 등의 방법[27]에 준하여 실험하였다. 주름조개풀 추출물 $0.1 \mathrm{~mL}$ 와 $1 \mathrm{~mL}$ 의 $0.2 \mathrm{M}$ Tris- $\mathrm{HCl}$ buffer $(\mathrm{pH} 8.0), 0.1 \mathrm{~mL}$ 의 0.8 $\mathrm{mM} \mathrm{N}$-succinyl-(Ala) $)_{3}$ - $\rho$-nitroanilide 기질 용액을 혼합하고, 1.0 $\mathrm{U} / \mathrm{mL}$ porcine pancreatice elastase (Sigma-Aldrich Co.) 농도 의 효소 $0.1 \mathrm{~mL}$ 을 첨가하여 $37^{\circ} \mathrm{C}$ 의 water bath에서 20 분간 시 약반응을 시켜 $\rho$-nitroaniline 생성량을 $410 \mathrm{~nm}$ 의 파장에서 흡광 도를 측정하였다.

\section{Collagenase 저해 효과 측정}

Elastin과 마찬가지로 피부 구조를 이루고 있는 collagen을 분해 하여 주름을 유발하는 효소인 collagenase 저해 효과를 측정하 기 위해 Wunsch와 Heidrich의 방법[28]에 준하여 실험하였다. $0.1 \mathrm{M}$ Tris- $\mathrm{HCl}$ buffer ( $\mathrm{pH} 7.5$ )에 $4 \mathrm{mM} \mathrm{CaCl}$ 를 첨가하여 제조한 용액과 주름조개풀 추출물 $0.1 \mathrm{~mL}$, 4-phenylazobenzyl oxycarbonyl-Pro-Leu-Gly- Pro-D-Arg $(0.3 \mathrm{mg} / \mathrm{mL})$ 농도의 기질

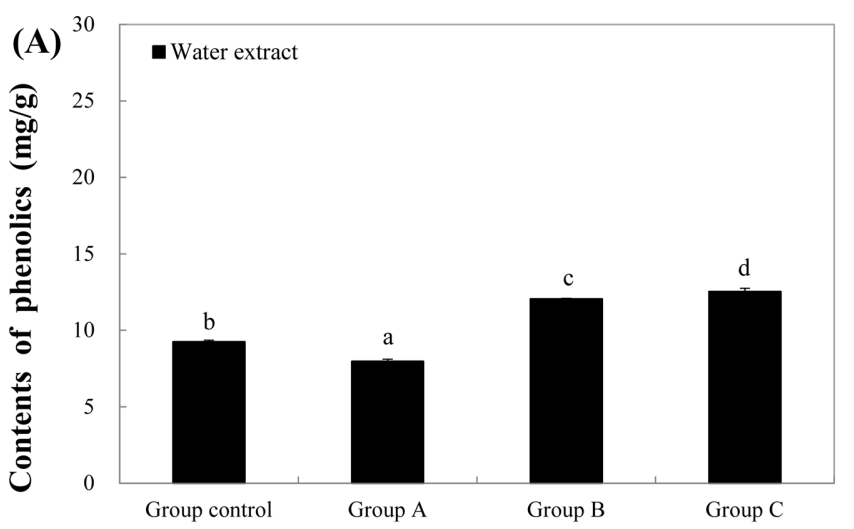

Content
용액 $0.25 \mathrm{~mL}$ 을 혼합한 후 $0.2 \mathrm{mg} / \mathrm{mL}$ collagenase (SigmaAldrich Co., Louis, MO, USA) 농도의 효소 용액 $0.15 \mathrm{~mL}$ 를 첨가하였다. 시약 반응은 실온에서 20 분간 반응시킨 후 $0.5 \mathrm{~mL}$ 의 $6 \%$ citric acid 종료시약을 넣어 반응을 정지시키고 ethyl acetate $2 \mathrm{~mL}$ 을 첨가하여 $320 \mathrm{~nm}$ 의 파장에서 흡광도를 측정하 였다.

\section{Hyaluronidase (HAase) 억제 효과 측정}

Hyaluronic acid (HA)의 분해를 촉매하는 효소인 HAase 저해 효과를 측정하기 위해 Dorfman와 Ott의 방법[29]에 준하여 실 험하였다. 주름조개풀 추출물 $0.5 \mathrm{~mL}$ 와 $20 \mathrm{mM}$ sodium phosphate buffer ( $\mathrm{pH}$ 6.9)에 녹인 HAase (1,000 U/mL) 0.5 $\mathrm{mL}$ 를 넣고 $38^{\circ} \mathrm{C}$ 의 water bath에서 5 분간 preincubation시킨다. $0.3 \mathrm{M}$ phosphate buffer $(\mathrm{pH} 5.3)$ 에 녹인 기질 용액 $(4 \mathrm{mg} / \mathrm{mL})$ $0.5 \mathrm{~mL}$ 를 첨가하고 다시 45 분간 water bath에서 reaction시킨 후 $5 \mathrm{~mL}$ 의 알부민용액을 첨가하여 5 분간 반응시키고 $600 \mathrm{~nm}$ 의 파장에서 투과율을 측정하여 대조구의 투과율과 비교하여 계산 하였다.

\section{통계처리}

모든 실험결과는 평균 \pm 표준편차(mean \pm standard deviation)로 표현하였다. 통계 분석은 최소 6개의 기술 복제물에 대한 실험 을 위해 SPSS 25 (Statistical Package for Social Science, Chicago, IL, USA)의 Duncan's multiple range test one way ANOVA 를 사용하여 수행되었다. $p<0.05$ 는 통계적으로 유의하다고 간 주되었다.

\section{결과 및 고찰}

\section{Elicitor 처리한 주름조개풀 추출물에 함유된 total phenolic compound의 함량 중대 효과}

식물 2차 대사산물의 한 종류로 식물계에 널리 분포되어 있으 며 생리활성에 관여한다고 알려져 있는 phenolic compounds는 대부분의 식물체에는 다량 함유되어 있으나 식물의 종류에 따

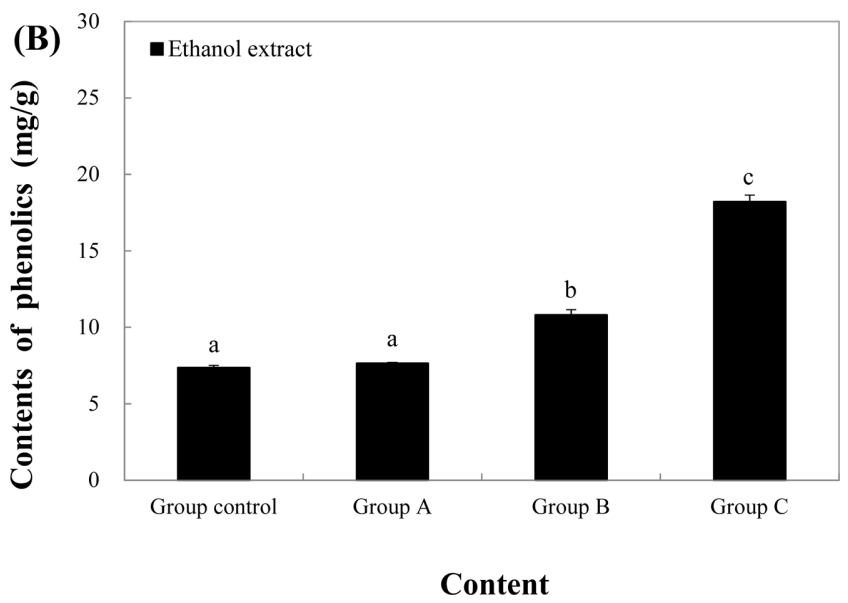

Fig. 1 Contents of total phenolics in extract from elicitor-treated group and non-treated group. Control: non elicitor, group A: 1 mg elicitor/mL, group B: $3 \mathrm{mg}$ elicitor $/ \mathrm{mL}$, group C: $5 \mathrm{mg}$ elicitor $/ \mathrm{mL}$. Means separation within columns by 5\% DMRT 
Table 1 Condition of HPLC analysis of extracts from Oplismenus undulatifolius

\begin{tabular}{ll}
\hline \hline Instrument & $\begin{array}{l}\text { HP HPLC series 1100 (Hewlett Packard, } \\
\text { Waldbronn, Germany) }\end{array}$ \\
& $\begin{array}{l}\text { Nova Pak } \mathrm{C}_{18} \text { column }(150 \mathrm{~mm} \times 3.9 \mathrm{~mm} \text { I.d, } \\
\text { Column }\end{array}$ \\
Waters, Milford, MA, USA) \\
Injection volume & $10 \mu \mathrm{L}$ \\
Analysis time & $40 \mathrm{~min}$ \\
Mobile phase A & A) Methanol B) distilled water $(\mathrm{A}: \mathrm{B}=70: 30)$ \\
Flow rate & $0.4 \mathrm{~mL} / \mathrm{min}$ \\
Column temperature & 35 \\
Detection & $\mathrm{UV}$ absorption $(230 \mathrm{~nm})$ \\
\hline
\end{tabular}

라 phenolic 성분들의 차이는 매우 다양하게 분포되어 있다. Phenolic compound는 분자구조에 hydroxyl기를 가지고 있기 때 문에 생리활성 효소 단백질들과 결합하여 질병을 억제하는 등 다양한 생리 기능을 가진다고 보고되어 있다[30,31]. 또한 $\mathrm{Cho[32]}$ 는 삼백초에 의해 발현되는 항산화, 고혈압 억제 및 통 풍 억제 등의 생리활성 등이 삼백초에 함유된 phenolic compound 에 의해 발현된다고 보고하였다.

Elicitor 처리군과 무처리군 추출물의 유용성분 함량의 변화를 비교하기 위해 안전하면서 유용성분을 가장 많이 추출할 수 있 는 용매로 열수와 에탄올을 선정하여, 대조군과 elicitor $1 \mathrm{mg} /$ $\mathrm{mL}$ 처리군을 $\mathrm{A}$ 그룹, $3 \mathrm{mg} / \mathrm{mL}$ 처리군을 $\mathrm{B}$ 그룹, $5 \mathrm{mg} / \mathrm{mL}$ 처리 군을 $\mathrm{C}$ 그룹으로 나누어 각 처리군별 분말 sample $1 \mathrm{~g}$ 을 물과 $70 \%$ 에탄올 $100 \mathrm{~mL}$ 에 침지시켜 24시간 동안 교반 추출하여 분 석용 추출물을 제조하였다. 주름조개풀 열수 추출물의 total phenolics 함량은 Fig. 1에서와 같이, 대조군, A, B, C그룹 순 으로 $9.24 \pm 0.12,7.97 \pm 0.14,12.06 \pm 0.04,12.52 \pm 0.23 \mathrm{mg} / \mathrm{g}$ 으로 elicitor를 $3 \mathrm{mg}$ 이상 처리한 group에서 phenol량의 증가가 관찰
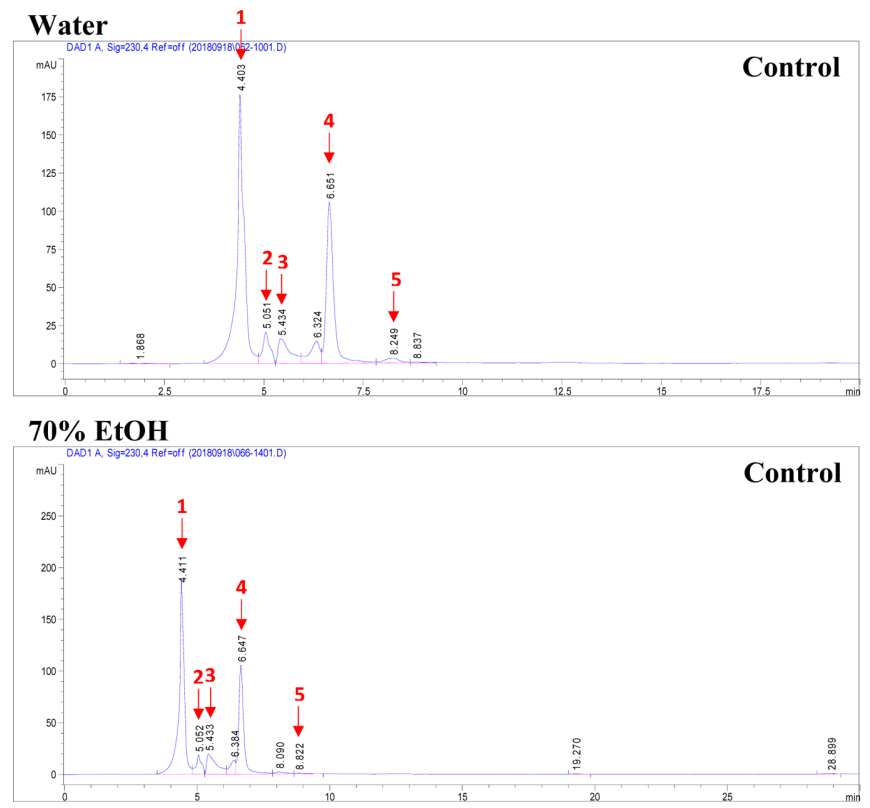

Fig. 2 Phenolic profile of extracts from Oplismenus undulatifolius by elicitor treatment. Control: non elicitor, Group C: $5 \mathrm{mg}$ elicitor/mL
되었으며, 에탄올 추출물의 total phenolics 함량은 대조군, $\mathrm{A}$, $\mathrm{B}, \mathrm{C}$ 그룹 순으로 $7.35 \pm 0.15,7.64 \pm 0.07,10.80 \pm 0.36$ 및 $18.22 \pm 0.42$ $\mathrm{mg} / \mathrm{g}$ 으로 elicitor가 처리되는 농도가 높아질수록 elicitor 처리에 의해 대조군보다 높은 함량을 나타내는 것을 확인하였다. 특히 에탄올 추출물에서 phenol성 물질의 함량이 열수 추출물에서 보 다 더 높아지는 경향을 나타내는 것은 Lee 등[33]의 보고에 따 라 생리활성에 관여하는 에탄올 추출물에서 phenol성 물질이 더 높아진다는 사실이 기능성 효과의 증대를 기대할 수 있다는 의 미에서는 더 효과적인 것으로 판단되었다.

\section{Elicitor처리한 주름조개풀 추출물의 phenolic profile 비교}

Elicitor 처리에 의해 stress를 받은 그룹이 식물 체내에 존재하 는 phytochemical 중 total phenolics 생산에 영향을 미칠 것으 로 예상되어 elicitor 처리군과 무처리군 추출물의 phenolics profile을 HPLC로 분석을 통해 확인하였다. Elicitor 처리에 따 른 주름조개풀 추출물 내 유용성분의 변화를 비교하기 위해 UV spectrophotometer를 이용하여 $200 \mathrm{~nm}$ 에서 $400 \mathrm{~nm}$ 까지 흡수선 량을 측정하였으며, 4 구간 모두 동일하게 가장 높은 측정값을 나타낸 $230 \mathrm{~nm}$ 를 최적 흡수파장으로 선정하여 Table 1에서의 조건에 따라 $\mathrm{HPLC}$ 를 이용하여 분석하였다.

그 결과 Fig. 2에서와 같이 열수 추출물에서는 무처리군인 대 조군의 4, 5, 6 min대의 $1,2,3,4$ 번 pick와 elicitor 처리군의 pick가 농도에 따라 큰 변화가 없는 것을 확인하였다. 반면 8 $\min$ 대의 5 번 pick의 경우, 무처리군인 대조군보다 elicitor 처리 군에서 증가하는 intensity를 나타내었다. 반면 에탄올 추출물에 서는 대조군의 4, 5 min대의 1,2 , 3번 pick와 elicitor 처리군 의 pick가 농도에 따라 큰 변화가 없는 것을 확인되었으나, 6 $\min$ 대의 4번 pick의 경우, 대조군보다 elicitor 처리군의 농도가 증가할수록 pick가 감소하는 intensity를 나타내었으며, 5번 pick 는 elicitor 처리군에 의해 높은 intensity를 나타내었다. 위의 결 과를 통해 주름조개풀의 생육 시 elicitor 처리에 의해 phytochemical

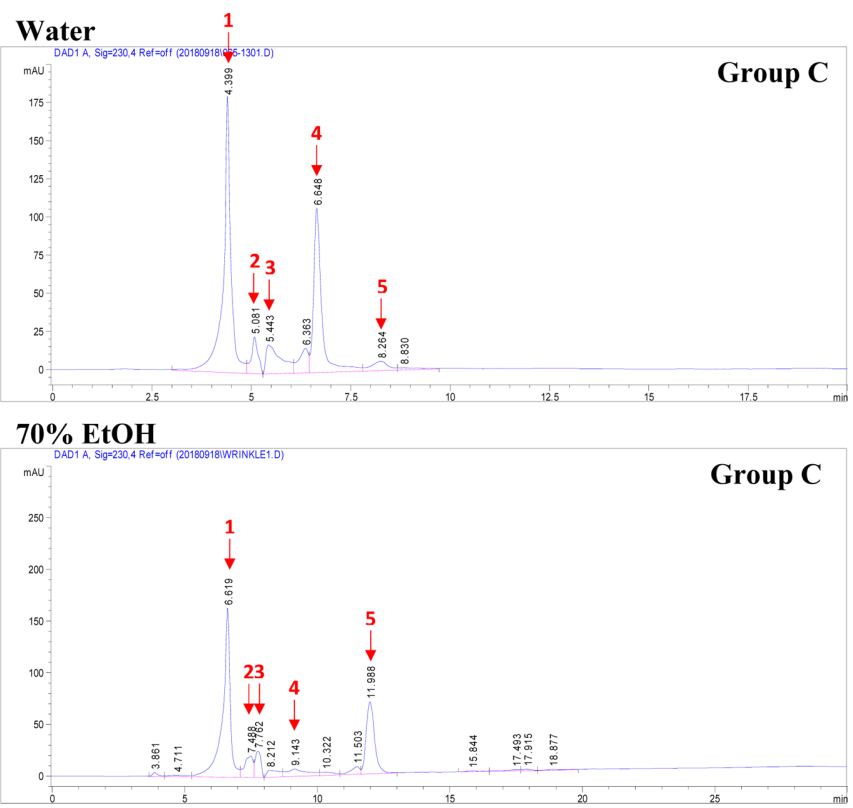




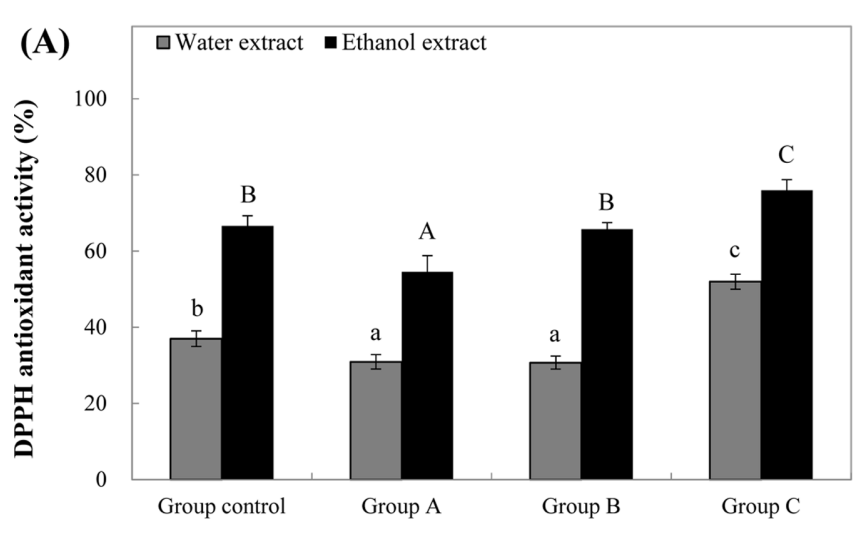

Extract content $(\mu \mathrm{g} / \mathrm{mL})$

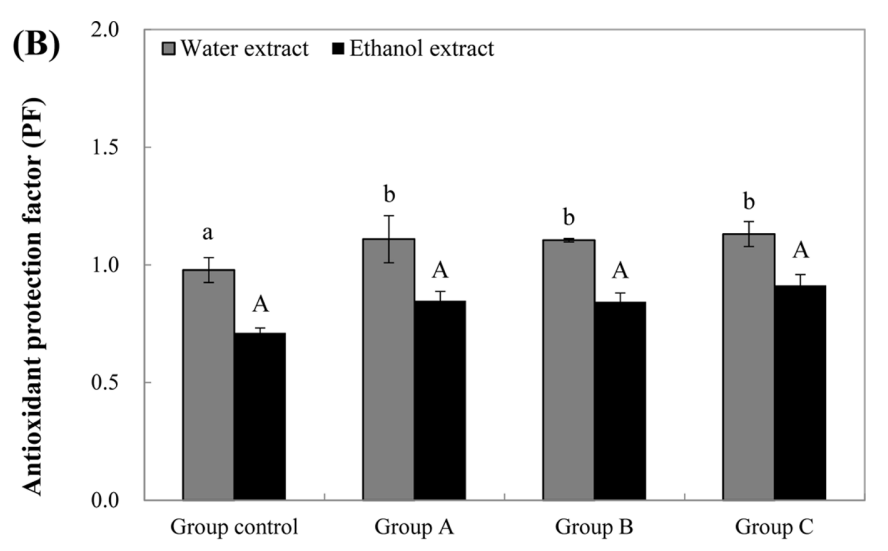

Extract content $(\mu \mathrm{g} / \mathrm{mL})$

Fig. 3 DPPH (A) and PF (B) of extracts from Oplismenus undulatifolius by elicitor treatment. Control: non elicitor, group A: 1 mg elicitor/mL, group B: $3 \mathrm{mg}$ elicitor/mL, group C: $5 \mathrm{mg}$ elicitor $/ \mathrm{mL}$. Means separation within columns by 5\% DMRT

물질인 phenolic 생성량이 증가하며, elicitor의 처리농도에 따라 phenolics profile도 변화되는 것을 확인하였다. 따라서 elicitor 처리한 주름조개풀의 각 추출물들이 다양한 생리활성에도 영향 을 미칠 것으로 예상되었다. Elicitor 처리에 의해 변화하는 phenolic profile의 변화에 대한 연구는 현재 진행되고 있으므로 향후 진행될 연구보고에 인용될 수 있을 것으로 기대된다.

\section{Elicitor 처리한 주름조개풀의 항산화 효과 중대}

앞의 결과에서 elicitor 처리에 의해 생성되는 phenolic compounds 의 농도 증가와 phenolics profile의 변화가 확인되었으나, 이러 한 phenolic의 변화가 생리활성에 미치는 영향을 살펴보기 위해 항산화를 포함한 각종 생리활성 효소의 활성을 측정하였다.

Elicitor 처리에 따라 변화된 phenolics 성상이 주름조개풀 추 출물의 항산화 기능에 변화를 주는지 확인하기 위해 항산화 효 능 중 $\mathrm{DPPH}$ radical 저해 효과와 PF 효과를 측정한 결과 Fig. 3에서와 같았다. 먼저 수용성 항산화력의 지표인 DPPH radical 저해 효과의 경우, 생리활성물질유도제(elicitor) 처리 농도에 따 라 Fig. $3 \mathrm{~A}$ 에서와 같이 저해율이 증가하는 양상을 나타내었고, 지용성 항산화 효능의 지표인 $\mathrm{PF}$ 효과 역시 Fig. $3 \mathrm{~B}$ 에서와 같 이 elicitor 처리에 따라 농도 의존적으로 $\mathrm{PF}$ 값이 증가하는 것 을 확인할 수 있었다. 이상의 결과에 따라 주름조개풀 재배 시 elicitor 처리로 생성된 새로운 phenolic 성분들이 항산화력을 증 가시키는 것으로 확인되었으며, 이들이 생리활성에 관여하는 것 으로 추측할 수 있었다.

\section{Elicitor 처리한 주름조개풀의 tyrosinase 억제 효과 중대} 일반적으로 사람의 피부는 멜라닌(melanin)이나 카로틴(carotene) 등과 같은 색소의 함량이나 각질층의 두께, 혈관의 분포도 등 과 같은 요인에 의해 색이 결정된다. 이 중 피부색을 결정하는 주요 요인인 멜라닌은 자외선을 어느 정도 차단하는 기능을 가 지지만, 얼굴, 손 등과 같이 외부에 노출되어 과도하게 멜라닌 이 합성되는 경우나 생성 메커니즘에 이상이 생길 경우 melasma, freckle 및 hyperpigmentation을 유발할 수 있다. 이와 같은 기능을 하는 멜라닌을 합성하는 기질인 tyrosine을 분해하

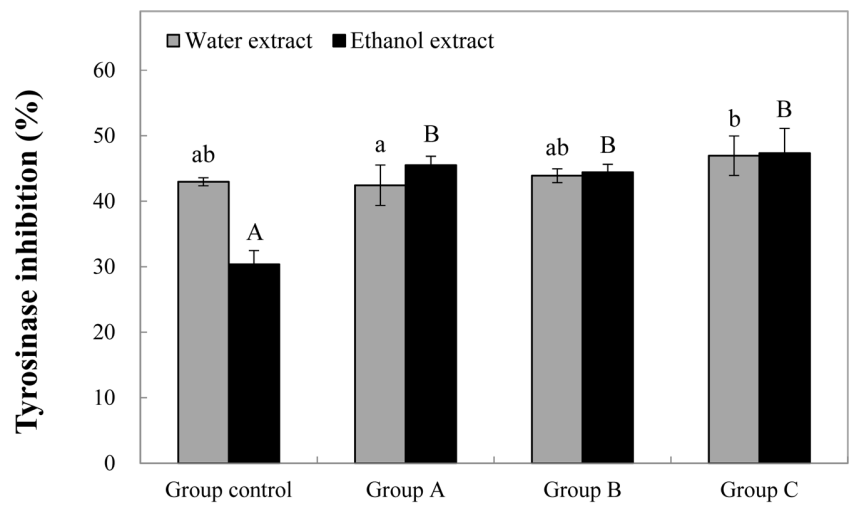

Extract content $(\mu \mathrm{g} / \mathrm{mL})$

Fig. 4 Inhibition of tyrosinase activity of extracts from Oplismenus undulatifolius by elicitor treatment. Control: non elicitor, group A: $1 \mathrm{mg}$ elicitor $/ \mathrm{mL}$, group B: $3 \mathrm{mg}$ elicitor $/ \mathrm{mL}$, group C: $5 \mathrm{mg}$ elicitor $/ \mathrm{mL}$. Means separation within columns by $5 \%$ DMRT 는 효소인 tyrosinase를 억제하여 간접적으로 미백효과를 측정
할 수 있다.
농도별로 elicitor를 처리하여 제조한 주름조개풀 추출물의 tyrosinase 억제 효과를 측정한결과 Fig. 4에서와 같이 대조군에 비해 elicitor 처리군 $\mathrm{A}, \mathrm{B}, \mathrm{C}$ 그룹에서 더 효과적인 효소억제 효능을 나타내어 멜라닌 형성 효소를 억제하는 것을 확인하였다.

\section{Elicitor 처리한 주름조개풀 추출물의 elastase 및 collagenase 억제 효과 중대}

Elastin은 진피 내 피부 탄력을 유지하는 기질 단백질 중 하나 이며, 인체의 중성구 과립구내에 존재한다. Elastin과 collagen은 중요한 기질 단백질인데 elastase는 이 단백질은 비특이적으로 가수분해하는 효소이다. 따라서 elastase를 저해하는 물질은 피 부 주름개선에 효능이 있다고 할 수 있으며, 현재 ursolic acid 등이 elastase 저해제로 주로 이용되고 있다. 또한 Giacomoni 


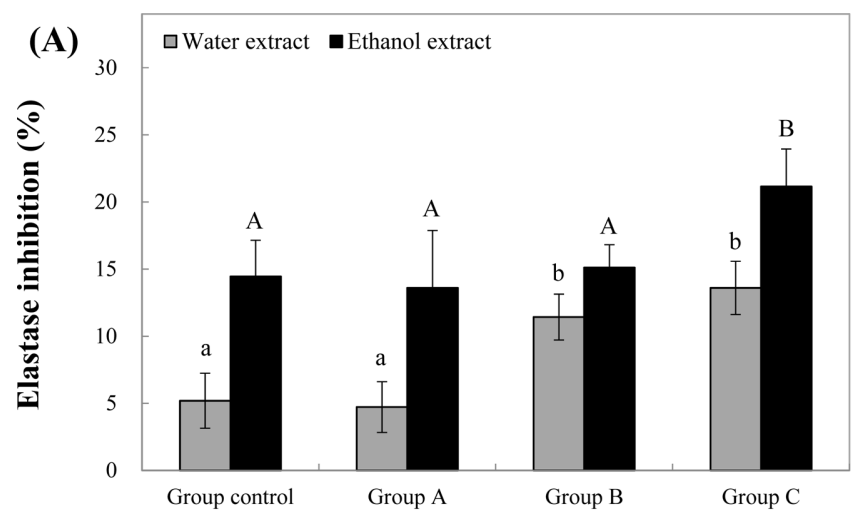

Extract content $(\mu \mathrm{g} / \mathrm{mL})$

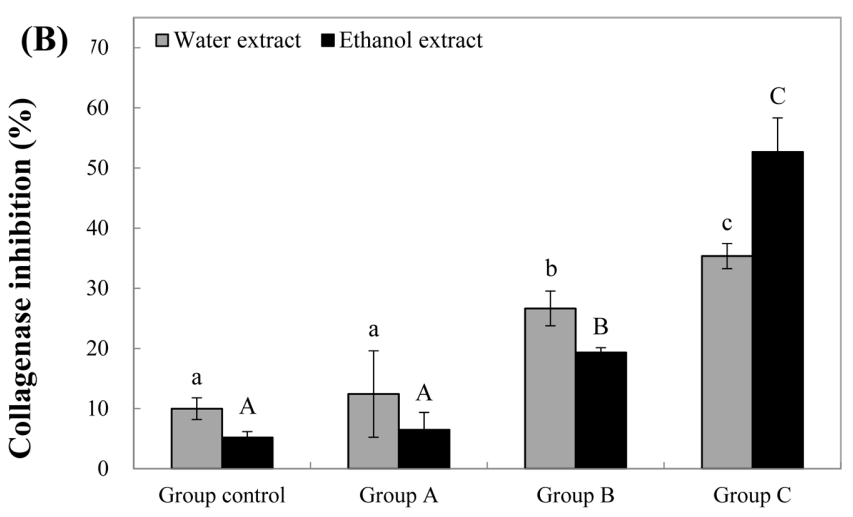

Extract content $(\mu \mathrm{g} / \mathrm{mL})$

Fig. 5 Inhibition of elastase (A) and collagenase (B) activity of extracts from Oplismenus undulatifolius by elicitor treatment. Control: non elicitor, group A: $1 \mathrm{mg}$ elicitor/mL, group B: $3 \mathrm{mg}$ elicitor/mL, group C: $5 \mathrm{mg}$ elicitor/mL. Means separation within columns by $5 \%$ DMRT

등[34]과 Cannell 등[35]은 elastaserk 체내의 elastin을 분해하는 백혈구 과립 효소 중의 하나로 이상조직에서 효소의 활성이 매 우 높아서 조직을 파괴하는 직접적인 원인이 되며, 피부주름 및 탄력성의 소실을 유발한다고 보고하였다. 또한 Collagen은 피부 의 진피층 결합조직의 구성원이고, 세포분할 및 분화 유도의 기 능을 가지고 있다. 이러한 collagen은 노화, 스트레스, 자외선 조 사와 같은 요인에 의해 collagenase의 활성이 증가함에 따라 collagen이 분해되어 감소하게 되며, 결국 피부의 탄력을 저하 시키고, 주름과 피부쳐짐을 유발하게 된다고 보고되어 있다[34]. 따라서 elastase 및 collagenase 저해활성을 측정함으로써 주름 개선의 효과와 상관있음을 알 수 있다.

Elicitor 처리한 주름조개풀 추출물의 elastase 및 collagenase 억제 효과는 Figs. 5A-B에서와 같이 비처리구인 대조구에 비해 elicitor 처리가 주름조개풀 추출물의 주름개선 효과의 증대에 매 우 큰 영향을 미치는 것으로 확인되었다. Elicitor의 처리에 의 해 열수 추출물 보다 에탄올 추출물에서 효소활성 억제 효과가 상대적으로 더 높게 나타나는 것으로 확인되었으며, elicitor의 처리 농도가 높아질수록 elastase와 collagenase의 억제 효과가 처리농도 의존적으로 가파르게 증가하는 것이 관찰되어 elicitor 의 처리농도를 높일수록 주름개선 효과가 우수한 기능성 화장 품 원료의 생산이 가능할 것으로 판단되었다.

\section{Elicitor 처리한 주름조개풀 추출물의 HAase 억제 효과}

진피층의 섬유아세포에서 산출되는 $\mathrm{HA}$ 는 고분자 다당으로, glucuronic acid와 glucosamine이 반족해서 연결된 점액성 moucopolysaccharide이다. 또한 대식세포의 phagocytic ability를 저해하기도 하며, $\mathrm{HA}$ 분해 산물 혹은 저분자 $\mathrm{HA}$ 의 기능으로 는 염증과 fibrosism, collagen deposition 등에 관여하여 상처 치유를 돕기도 한다. 이러한 고분자의 $\mathrm{HA}$ 를 분해하는 효소인 HAase의 저해에 의해 HA의 고분자 형태를 유지하게 함으로서 항염증 효과를 기대할 수 있다[36].

Elicitor 처리한 주름조개풀 추출물의 염증 억제 효과는 Fig. 6 에서와 같이 비처리구인 대조구에 비해 열수 추출물에서는 효 소활성이 관찰되지 않았으나, 에탄올 추출물에서는 elicitor를 처

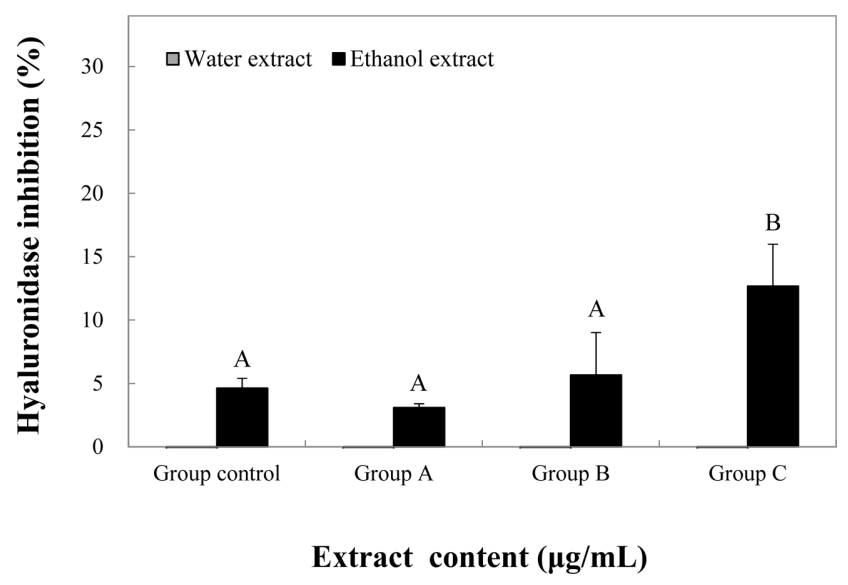

Fig. 6 Inhibition of hyaluronidase activity of extracts from Oplismenus undulatifolius by elicitor treatment. Control: non elicitor, group A: $1 \mathrm{mg}$ elicitor $/ \mathrm{mL}$, group B: $3 \mathrm{mg}$ elicitor $/ \mathrm{mL}$, group C: $5 \mathrm{mg}$ elicitor $/ \mathrm{mL}$. Means separation within columns by $5 \%$ DMRT

리에 의해 농도 의존적으로 우수한 염증 억제 효과를 나타내어 elicitor 처리가 유용물질의 산업화라는 전제를 충족시키기 위한 biomass 기법으로 매우 적당하다는 것을 시사해주었다.

위의 결과에 따라 elicitor를 처리하여 수확한 주름조개풀의 단위 무게당 활성물질인 phenolic compounds의 함유량 또는 생 산량을 높이고, 생리활성에 영향을 미치는 효소의 억제를 통해 천연물 기반의 유용물질 증폭, 효율적인 원료 생산, 및 재배기 법의 진화에 활용할 수 있다고 판단되었다.

\section{초 록}

본 연구에서는 생리활성물질유도제인 elicitor를 처리한 주름조 개풀의 열수, 에탄올 추출물들의 항산화 효과, tyrosinase, elastase, collagenase 및 HAase 등의 미용관련 생리활성의 변화 
를 살펴보았다. Elicitor 처리한 주름조개풀 추출물의 DPPH 및 $\mathrm{PF}$ 등의 항산화 효과는 elicitor 비처리구인 대조구에 비해 elicitor 처리구가 농도의존적으로 더 높은 항산화 활성을 나타 내었다. Elicitor 처리한 주름조개풀 추출물의 미용활성은 elastase 및 collagenase 억제 효과에 의한 주름개선효과와 tyrosinase 저 해에 의한 미백효과가 비처리구인 대조구에 비해 상대적으로 매 우 높은 효소 억제 효과를 나타내어 elicitor 처리가 주름조개풀 추출물의 미백 및 주름개선 효과의 증대에 크게 영향을 미치는 것으로 확인되었으며, 농도의존적인 양상을 나타내었다. 또한 HAase 억제에 의해 유래되는 염증 억제 효과도 비처리구인 대 조구에 비해 에탄올 추출물에서 우수한 염증 억제 효과를 나타 내었다. Elicitor 처리에 의해 대조구에 비해 처리구에서 생리활 성 효소에 대한 억제율이 큰 폭으로 상승하는 효과를 나타내 어, elicitor 처리가 유용물질의 산업화라는 전제를 충족시키기 위한 biomass 기법으로 매우 적당하다는 것을 시사해주었다. 따 라서 주름조개풀 노지재배 시에 본 연구에서 사용한 elicitor를 처리하면 수확되는 주름조개풀의 단위 무게 당 유용물질의 생 산량을 높일 수 있고, 생리할성도 증대시킬 수가 있어 산업화 를 위한 고기능성 원료생산에 효율적인 재배기법으로 활용할 수 있을 것이라 판단되었다.

Keywords 생리활성물질유도제 - 생리활성효소 · 주름조개풀 · 증대효과 · 항산화

\section{References}

1. Lee JE, Lee EH, Kim BO, Cho YJ (2017) Biological activities of extracts from Caryopteris incana Miq. Appl Biol Chem 60: 61-68

2. Lee EH, Kim BO, Cho YJ (2017) Inhibitory activities on biological enzymes of extracts from Oplismenus undulatifolius. J Appl Biol Chem 60: $101-108$

3. Chiba K, Kawakami K, Sone T, Onoue M (2003). Characteristics of skin wrinkling and demal changes induced by repeated application of squalene monohydroperoxide to hairless mouse skin. Skin Pharmacol Appl Skin Physiol 16: 242-251

4. Mukhtar H, Elmets CA (1996) Photocarciongenesis mechanisms, models and human health implications. Photochem Photobiol 63: 356-357

5. Kohno Y, Takahashi M (1995). Peroxidation in human skin and its prevention. J Jap Oil Chem Soc 44: 10-17

6. Bernstein EF, Chen YQ, Tamai K, Shepley KJ, Resnik KS, Zhang H, Tuan R, Mauviel A, Uitto J (1994) Enhanced elastin and fibrillin gene expression in chronically photodamaged skin. J Invest Dermatol 103: 182-186

7. Gilchrest BA (1990) Skin aging and photoaging. Dermatol Nurs 2: 79 82

8. Mauviel A, Halcin C, Vasiloudes P, Parks WC, Kurkinen M, Uitto J (1994) Uncoordinate regulation of collagenase, stromelysin, and tissue inhibitor of metalloproteinases genes by prostaglandin E2: Selective enhancement of collagenase gene expression in human dermal fibroblasts in culture. J cell Biochem 54: 465-472

9. Park SK, Kim SN, Lee JC, Kim HS, Kim YJ, Lee BG, Chang IS (2004) Anti-aging effect on skin with Jaeum-Dan (JED). Kor J Herb 19: 67-76

10. Pentland AP, Shapiro SD, Welgus HG (1995) Agonist-induced expression of tissue inhibitor of metalloproteinases and metalloproteinases by human macrophages is regulated by endogenous prostaglandin $E_{2}$ synthesis. J Invest Dermatol 104: 52-57

11. Rice-Evans CA, Miller NJ, Paganga G (1996) Structure-antioxidant activity relationships of flavonoids and phenolic acids. Frdd Rad Biol Med 20: 933-956

12. Kinsella JE, Frankel E, German B, Kanner J (1993) Possible mechanism for the protective role of antioxidants in wine and plant foods. Food Technol 47: 85-89

13. Lee YS, Yoon HK, Kim NW (2010) The physiological activities of ripe fruit of Poncirus trifoliata. Kor J Food Preserv 17: 698-705

14. Korea forest seed and variety center (KFSV) (2009) Life characteristics of plant resources from Korea forest. Chungju

15. Posner BM, Saffel-shrier S, Dwyer J, Franz MM (2000) Position of the american dietetic association: nutrition, aging, and the continuum of health care. J Am Diet Assoc 100: 580-595

16. Lee TB (1999) Illustrated flora of Korea. Hyangmunsa, Seoul

17. Ohmoto T, Ikuse M (1970) Triterpenoids of the gramineae. Phytochemistry 9: 2137-2148

18. Ko SH (2008) Nanodispension and nanoparticle using foodgrade materials. J Food Sci Ind 41: 25-31

19. Choe KH (1999) A study on chemical composition and anti-microbial activity of Saururaceae growing in Korea. Dissertation, Kyung Hee University

20. Choe KH, Yoon CH, Kwon SJ (1994) A study on chemical composition of Saururaceac growing in Korean on flavonoid constituents of Saururus chinensis. J Kor Soc Anal Sci 7: 11-15

21. Cho YJ, Park SY, Kim KB (2014) Preparing methods of Saururus chinensis increased inhibitory compounds against gastritis using hydrolyzed yeast with enzyme. Patent 10-1469901, 1 Dec 2014

22. Park SY, Song IH, Cho YJ (2018) Elicitor treatment potentiates the preventive effect of Saururus chinensis leaves on stress-induced gastritis. Appl Biol Chem 61: 423-431

23. Folin O, Denis W (1912) On phosphotungstic-phosphomolybdic compounds as colcor reagents. J Biol Chem 12: 239-243

24. Blois MS (1958) Antioxidant determinations by the use of a stable free radical. Nature 181: 1199-1200

25. Andarwulan N, Shetty K (1999) Phenolic content in differentiated tissue cultures of untransformed and Agrobacterium-transformed roots of anise (Pimpinella anisum L.). J Agric Food Chem 47: 1776-1780

26. Vincent J, Hearing JR (1987) Mammalian monophenol monooxygenase (tyrosinase): Purification, properties, and reactions catalyzed. Method Enzymol 142: 154-165

27. Kraunsoe JA, Claridge TD, Lowe G (1996) Inhibition of human leukocyte and porcine pancreatic elastase by homologues of bovine pancreatic trypsin inhibitor. Biochemistry 35: 9090-9096

28. Wunsch E, Heidrich HG (1963) Zur quantitativen bestimmung der kollagenase. Hoppe-Seyler's Physiol Chem 333: 149-151

29. Dorfman A, Ott ML (1948) A turbidimetric method for the assay of hyaluronidase. J Biol Chem 172: 367-375

30. Choi YM, Kim MH, Shin JJ, Pack JM, Lee JS (2003) The antioxidant activities of the some commercial teas. J Kor Soc Food Sci Nutr 32: $723-727$

31. Cho YJ (2012) Charactrization of biological activities of Rehmannia glutinosa extracts. J Life Sci 22: 943-949

32. Cho YJ (2014) Antioxidant, angiotensinconverting enzyme and xanthin oxidase inhibitory activity of extracts from Saururus chinensis leaves by ultrafine grinding. Kor J Food Preserv 21: 75-81

33. Lee EH, Kim BO, Cho YJ (2017) Inhibitory activities on biological enzymes of extracts from Oplismenus undulatifolius. J Appl Biol Chem 60: $101-108$

34. Giacomoni PU, Rein G (2001) Factors of skin ageing share common mechanism. Biogerontol 2: 219-229

35. Cannell RJP, Kellan SJ, Owsianks AM, Walker JM. (1988) Results of a large scale scrren of microalgae for the production of protease inhibitors. Planta Med 54: 10-14

36. Ghosh P (1994) The role of hyaluronic acid (hyaluronan) in health and disease: Interactions with cells, cartilage and components of synovial fluid. Clin Exp Rheumatol 12: 75-82 